\title{
The Role of Prokineticins in the Pathogenesis of Hypogonadotropic Hypogonadism
}

\author{
Ana Paula Abreu ${ }^{a}$ b Ursula B. Kaiser ${ }^{b} \quad$ Ana Claudia Latronico ${ }^{a}$ \\ a Unidade de Endocrinologia do Desenvolvimento, Laboratório de Hormônios e Genética Molecular, LIM/42, \\ Hospital das Clínicas, Faculdade de Medicina da Universidade de São Paulo, São Paulo, Brasil; bivision of \\ Endocrinology, Diabetes and Hypertension, Brigham and Women's Hospital and Harvard Medical School, \\ Boston, Mass., USA
}

\section{Key Words}

Prokineticins $\cdot \mathrm{GnRH}$ secretion · Kallmann syndrome •

Hypogonadotropic hypogonadism

\section{Abstract}

The prokineticin system comprises two multifunctional secreted proteins, prokineticin-1 (PROK1) and prokineticin-2 (PROK2), and their cognate $G$ protein-coupled receptors. The prokineticins were originally identified as endogenous regulators of gastrointestinal motility. Currently, these bioactive peptides are involved in a wide spectrum of biological functions, including angiogenesis, neurogenesis, circadian rhythms, nociception, hematopoiesis and immune response. Mice homozygous for null mutations in Prokr2 or Prok2 recapitulate the human phenotype of Kallmann syndrome, exhibiting severe atrophy of the reproductive system and hypoplastic olfactory bulbs. Indeed, the evidence from several naturally inactivating mutations in the PROK2 and PROKR2 genes in patients with Kallmann syndrome and normosmic hypogonadotropic hypogonadism also indicate the essential role of PROK2 in olfactory bulb morphogenesis and $\mathrm{GnRH}$ secretion in humans.

Copyright $\odot 2010$ S. Karger AG, Basel

\section{Introduction}

The prokineticin system comprises two closely related proteins, prokineticin-1 (PROK1; also called EG-VEGF) and prokineticin-2 (PROK2; also called Bv8), and their cognate $G$ protein-coupled receptors, PROKR1 and PROKR2 [1, 2]. Prokineticins are cysteine-rich secreted proteins that were originally identified as potent agents mediating gut motility in the digestive system, but were later shown to promote diverse biological functions, including normal development of the olfactory bulb and sexual maturation [1].

The mature forms of PROK 1 and PROK2 consist of 86 and 81 amino acids, respectively [1]. These proteins are approximately $50 \%$ homologous to each other and share the identical amino terminal hexapeptide (AVITGA), which is crucial for their biological activities [2]. Both contain carboxyl-terminal cysteine-rich domains that form five disulfide bridges with conserved spacing. Substitutions, deletions and insertions to the conserved amino-terminal hexapeptide or mutations affecting selected cysteine residues in the carboxy-terminal domain result in prokineticins without biological activity [2].

\section{KARGER}

๑) 2010 S. Karger AG, Basel

Fax +4161306 1234

E-Mail karger@karger.ch

www.karger.com
Accessible online at: www.karger.com/nen
Ana C. Latronico

Hospital das Clínicas, Faculdade de Medicina da Universidade de São Paulo Disciplina de Endocrinologia e Metabologia, Av. Dr. Eneas de Carvalho Aguiar $1552^{\circ}$ andar Bloco 6, São Paulo, SP 05403900 (Brasil)

Tel./Fax +55 11 30697519, E-Mail anacl@usp.br 
PROK1, an angiogenic mitogen for endocrine gland vascular endothelium [3], is encoded by a small gene mapped on chromosome 1 (NCBI Gene ID: 84432). PROK2 is encoded by the PROK2 gene on $3 \mathrm{p} 13$ and contains 4 exons (NCBI Gene ID: 60675). The most active form of PROK2 with 81 amino acids is encoded by the exons 1,2 and 4. Molecular cloning analysis has further identified a long form of the PROK2 peptide, PROK2L, with 21 additional amino acids, encoded by all 4 exons of PROK2 [4]. PROK1 and PROK2 are expressed in the adrenal gland, brain, testis, intestinal tract, heart, bone marrow and peripheral blood [5]. PROK1 is expressed in the ovary, uterus and placenta in response to hormonal changes across the menstrual cycle and during pregnancy $[5,6]$. PROK2 exhibits circadian rhythmic expression in the suprachiasmatic nucleus $[7,8]$.

Prokineticin receptors belong to the family of $\mathrm{G}$ protein-coupled receptors. PROKR1 and PROKR2 show strong similarity in their primary structure $(87 \%$ homology) [9-11]. PROK1 and PROK2 can bind and activate both receptors, although they exhibited a slightly higher binding affinity for PROKR2 when compared with PROKR1. PROK2 has the highest affinity for both receptors [9-11]. PROK2L displays strong receptor selectivity for PROKR1 over PROKR2 [2, 4]. Activation of prokineticin receptors, which couple to Gq protein, leads to mobilization of calcium, stimulation of phosphoinositide turnover and activation of $\mathrm{p} 42 / \mathrm{p} 44 \mathrm{MAPK}$ signaling pathways [9-11]. The prokineticin receptors can also couple to Gi and Gs proteins $[4,12]$. PROKR1 shows preferential distribution in the peripheral tissues, whereas PROKR2 shows relatively localized distribution in the central nervous system [9].

Prok2 and Prokr2 are expressed in the ependymal and subependymal layers of the olfactory bulbs, preoptic area and median eminence in mice $[13,14]$. It has been demonstrated that the prokineticins play an essential role in olfactory bulb morphogenesis [14], and this system may also be involved in the migration/survival of GnRH neurons.

\section{Animal Models}

The generation of Prok2 and Prokr2 knockout (KO) mice demonstrated the importance of these genes in normal olfactory bulb development and sexual maturation. Both Prok2 and Prokr2 KO mice displayed defects in the olfactory bulb, with Prok2 KO mice showing reduced olfactory bulb size, loss of normal olfactory bulb architec- ture and accumulation of neuronal progenitors in the rostral migratory stream [14]. Prokr2 KO mice showed olfactory bulb hypoplasia during early fetal development [15].

Several abnormalities in reproductive organs were also observed in the Prokr2 KO mice, including severe atrophy of the testes, ovaries, uterus, vagina and mammary glands. Immunohistochemical analysis of $\mathrm{Prokr}^{-/-}$ mice showed an absence of GnRH-immunoreactive neurons in the preoptic area and median eminence of the hypothalamus, which correlated with reduced mRNA levels of hypothalamic GnRH and pituitary gonadotropins as well as decreased plasma levels of testosterone and FSH [15]. Interestingly, GnRH neurons in Prok $2^{-/-}$mice were able to cross the cribriform plate to enter the central nervous system during embryonic development, but the neurons did not migrate into and populate the hypothalamus [16]. The remarkable phenotypic similarities between Prokr2 ${ }^{-/}$and Prok2 $2^{-/-}$mice and Kallmann syndrome in humans inspired the hypothesis that inactivating mutations in the prokineticin system could lead to anosmia and hypogonadotropic hypogonadism in humans.

The rhythmic expression of PROK2 in the suprachiasmatic nucleus, the expression of PROKR2 in most primary target areas of the suprachiasmatic nucleus and the control of PROK2 expression/release by core clock genes [7] led to the evaluation of the circadian rhythms in Prok2 and Prokr2 $\mathrm{KO}$ mice. As anticipated, these mice exhibited disruption of circadian rhythms, with reduced rhythmicity of locomotor activity, body temperature and sleep [17-20].

\section{Human PROK2 and PROKR2 Mutations}

Kallmann syndrome is a complex developmental disorder combining congenital hypogonadotropic hypogonadism with anosmia or hyposmia. This phenotype is related to failure of embryonic migration of $\mathrm{GnRH}$ and olfactory neurons [21]. Kallmann syndrome is genetically heterogeneous [22]. Loss-of-function mutations in KAL1, FGFR1, FGF8 or CHD7 underlie either X-linked recessive or autosomal dominant forms of the disease [23-28]. Human PROK2 and PROKR2 mutations were first described in 2006. Dodé et al. [29] studied a cohort of 192 patients with Kallmann syndrome, and mutations in PROK2 and PROKR 2 were identified in 2 and $7 \%$ of the patients, respectively. Since then, approximately nine different mutations of PROK2 and 24 mutations of PROKR2 have been 
reported in patients with variable degrees of $\mathrm{GnRH}$ deficiency and olfactory abnormalities (fig. 1a, b) [16, 29-36].

These mutations have been found in both male and female patients from a broad range of ethnic backgrounds $[16,29,30,34]$. Complete and partial hypogonadotropic hypogonadism as well as delayed puberty have been associated with PROK2 and PROKR2 mutations. Additional clinical anomalies frequently described in patients with Kallmann syndrome caused by KAL1 or FGFR1 mutations were rarely described in patients with $P R O K 2$ or PROKR 2 mutations. Five cases of high arched palate [30, $36]$, four cases of bimanual synkinesia [34,36], three cases of hearing loss $[34,36]$, three cases of pectus excavatum $[30,34]$ and one case of hypodontia were described [36]. No cases of renal agenesis or cleft lip/palate were reported.

Prokineticins have been implicated in circadian rhythms, and it is speculated that patients with mutations in these genes may have circadian rhythm alterations. In one study, a Kallmann syndrome patient with a PROK2 p.R73C mutation exhibited a severe sleep disorder, suggesting a potential contribution of the PROKR2 signaling to physiological sleep-wake cycle [29]. However, in another recent study, patients with PROKR2 or PROK2 mutations did not show sleep abnormalities or circadian cortisol pattern alterations [36]. A more detailed investigation is necessary to determine whether mutations in PROK2 or PROKR2 lead to disruption in circadian rhythms in humans.

Initially, a genotype/phenotype association of the PROK2 and PROKR2 mutations in Kallmann syndrome was exclusively based on the absence of the genetic variants in control groups and their localization in conserved amino residues [29]. Intriguingly, most of the described variants of PROK2 and PROKR2 were missense mutations found in the heterozygous state, and only nine of them (3 in PROK2, fig. 1a, and 6 in PROKR2, fig. 1b) were identified in the homozygous state $[16,30-32,36]$. Notably, segregation analysis of two homozygous deleterious mutations of PROK2 (p.I55fsX1) and PROKR2 (p.Y140X) revealed that asymptomatic relatives also carried the same mutations in the heterozygous state, indicating that haploinsufficiency was not sufficient to cause the hypogonadotropic hypogonadism phenotype $[16,30]$. This finding was in agreement with the report that only homozygous null mice for Prok 2 or Prokr 2 exhibited abnormal phenotypes [15]. Therefore, the role of heterozygous mutations in PROK2 and PROKR2 remains unclear.

Definitely one of the major challenges in the genetic investigation of human prokineticin defects is to under- stand their inheritance pattern. Undiscovered mutations in promoter or intronic regions of the PROK2 or PROKR 2 genes in association with heterozygous mutations within the coding regions could explain some of the unresolved phenotype-genotype correlations. Another appealing possibility is the existence of digenic or oligogenic inheritance in some of these families with heterozygous PROK2 and PROKR 2 mutations. Indeed, approximately $10 \%$ of the patients with heterozygous mutations of PROK2 or PROKR2 harbored mutations in other genes (table 1); however, the functional role of some of these genetic variants has not been well defined by in vitro studies [29, 3336]. Alternatively, the presence of polymorphisms, epigenetic and environmental effects are other potential factors that should be considered.

A comparative phenotypic study involving 55 patients, including 42 men and 13 women with Kallmann syndrome who carried either monoallelic or biallelic mutations in PROK2 or PROKR2 was recently conducted by several groups of investigators in France [36]. Male patients carrying biallelic mutations generally had a less variable and more severe reproductive phenotype than patients carrying monoallelic mutations. A high prevalence of both micropenis and cryptorchidism, and a lower mean testicular volume were noted in male patients with biallelic mutations. Their hormonal profile was also different, with lower testosterone, basal FSH and GnRHstimulated LH levels in patients with biallelic mutations. Interestingly, nonreproductive and nonolfactory clinical anomalies were restricted to Kallmann syndrome patients with monoallelic mutations [36].

\section{In vitro Functional Studies of $P R O K 2$ and $P R O K R 2$ Mutants}

In vitro functional studies of $P R O K 2$ and $P R O K R 2$ mutants have been reported, establishing the causal role of mutations described in these genes [16, 34, 37]. In a comprehensive study of 324 patients with either Kallmann syndrome or normosmic hypogonadotropic hypogonadism, five mutations in $P R O K 2$ and ten mutations in PROKR2 were identified (fig. 1a, b). The ability of PROK2 mutant proteins to activate intracellular $\mathrm{Ca}^{2+}$ mobilization in cells expressing PROKR2 was assessed using an aequorin-based luminescent assay. The PROK2 mutations p.C34Y, p.R73C and p.I55fsX1 resulted in inactivation or markedly reduced activity of the peptide (table 2). The p.I55fsX1 is a frameshift mutation that introduces a premature stop codon, which results in the production of 


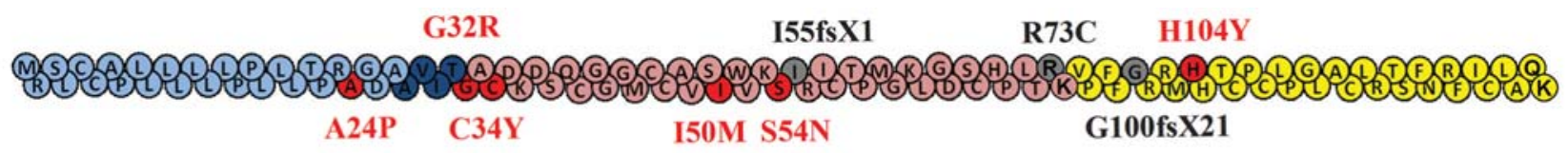

a

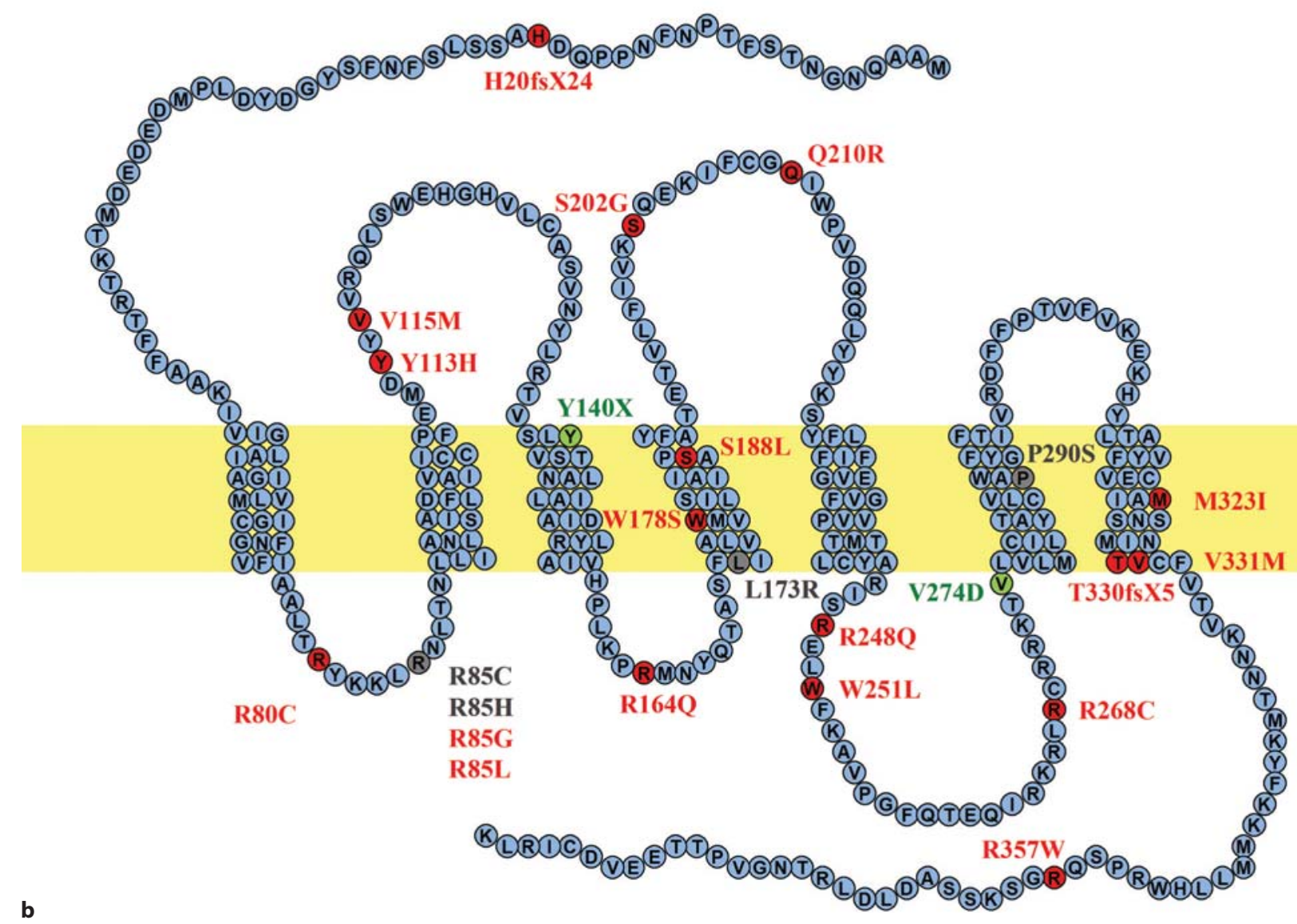

Fig. 1. Mutations identified in PROK2 and PROKR2. The mutations identified in the heterozygous state are shown in red, the mutations identified in both homozygous and heterozygous states are shown in gray and the mutations identified only in the homozygous state are shown in green. a Peptide sequence of PROK2 (81 amino acids) with the signal peptide (27 amino acids, shown in light blue). Exon 1 includes the signal peptide and the amino acids shown in dark blue. Exon 2 is shown in pink and exon 4 in yellow. Exon 3 is not shown. No mutations have been identified in exon 3. b Schematic representation of PROKR2. a truncated protein that lacks the cysteine-rich domains critical for biological activity. The mutations p.C34Y and p.R73C are predicted to disrupt disulfide bond formation. However, a p.I50M mutation was not shown to affect the function of the peptide (table 2). Indeed, both me- thionine and isoleucine are neutral amino acids and, therefore, this amino acid change at codon 50 of the PROK2 does not result in a significant alteration of protein charge. A p.A24P mutation, located in the signal peptide, was not tested [34]. 
Table 1. Eight patients who harbored $P R O K R 2$ mutations associated with other gene defects

\begin{tabular}{|c|c|c|c|c|}
\hline Patient & Mutations & Diagnosis & Functional consequence & References \\
\hline 1 & PROKR2 p.L173R + KAL1 p.S396L & KS & $\begin{array}{l}\text { PROKR2: } \downarrow \text { signaling } \\
\text { KAL1: not reported }\end{array}$ & {$[29,36]$} \\
\hline 2 & $\begin{array}{l}\text { PROKR2 p.L173R + KAL1 p.E514K } \\
\text { (polymorphism -rs28937309) }\end{array}$ & KS & $\begin{array}{l}\text { PROKR2: } \downarrow \text { signaling } \\
\text { KAL1: altered function }\end{array}$ & {$[33]$} \\
\hline 3 & $\begin{array}{l}\text { PROKR2 p.V115M + PROK2 } \\
\text { p.A24P }\end{array}$ & KS & $\begin{array}{l}\text { PROKR2: } \downarrow \text { signaling } \\
\text { PROK2: not reported }\end{array}$ & {$[34]$} \\
\hline 4 & $\begin{array}{l}\text { PROKR2 p.S202G + GnRH1 } \\
\text { p.R31C + FGFR1 p.I239T }\end{array}$ & $\mathrm{nIHH}$ & $\begin{array}{l}\text { PROKR2: not reported } \\
\text { GnRH1: not reported } \\
\text { FGFR1: not reported }\end{array}$ & {$[35]$} \\
\hline 5 & $\begin{array}{l}\text { PROKR2 p.R85L + FGFR1 } \\
\text { p.A604T }\end{array}$ & KS & $\begin{array}{l}\text { PROKR2 and FGFR1: } \\
\text { not reported }\end{array}$ & {$[36]$} \\
\hline 6 & $\begin{array}{l}\text { PROKR2 p.L173R + KAL } \\
\text { p.R423X }\end{array}$ & $\mathrm{KS}$ & $\begin{array}{l}\text { PROKR2: } \downarrow \text { signaling } \\
\text { KAL1: PTC }\end{array}$ & [36] \\
\hline 7 & $\begin{array}{l}\text { PROKR2 p.R268C + KISS1R } \\
\text { p.A189T }\end{array}$ & KS & $\begin{array}{l}\text { PROKR2: } \downarrow \text { signaling } \\
\text { KISS1R: not reported }\end{array}$ & {$[36]$} \\
\hline 8 & $\begin{array}{l}\text { PROKR2 p.V331M + GNRHR } \\
\text { p.R240Q }\end{array}$ & KS & $\begin{array}{l}\text { PROKR2: } \downarrow \text { signaling } \\
\text { GnRHR: not reported }\end{array}$ & [36] \\
\hline
\end{tabular}

$\mathrm{KS}=$ Kallmann syndrome; $\mathrm{nIHH}=$ normosmic isolated hypogonadotropic hypogonadism; $\mathrm{PTC}=$ premature termination codon.

Table 2. Functional effects of $P R O K 2$ mutations as determined by in vitro studies

\begin{tabular}{llll}
\hline Mutation & Calcium mobilization & Potential mechanism & References \\
\hline p.C34Y & no activity & disruption of disulfide bridges & {$[34]$} \\
p.I50M & similar to wild-type & does not alter the hydrophobic properties of the amino acids & {$[34]$} \\
p.I55fsX1 & no activity & truncated protein & {$[16,34]$} \\
p.R73C & $60 \% \downarrow$ & disruption of disulfide bridges & {$[34]$} \\
\hline
\end{tabular}

Some mutations identified in $P R O K R 2$ were tested using experiments that measured cell surface expression, ligand binding and signal transduction through the activation of $\mathrm{G} \alpha_{\mathrm{q}}$, calcium mobilization (aequorin-based luminescence, Fluo-4 fluorescence) and MAPK pathway activation (Egr1-luciferase) [34, 37]. The amount of the receptor in the plasma membrane was quantified by ELISA in nonpermeabilized cells and compared to permeabilized cells. Mutations in the extracellular loops severely compromised signal transduction (table 3 ). These mutations most likely interfere with ligand binding, as shown in the binding study of the mutation p.Q210R located in the second extracellular loop [37]. The mutations in the intracellular loops and in the carboxy-terminal domain affect the function of the receptor to variable degrees (table 3 and fig. $1 \mathrm{~b})$.

The exact mechanisms by which each of these mutations affect the function of the receptor are not known, but it is likely that they can interfere with $G$ protein activation or with the correct transport of the receptor to the plasma membrane. This last hypothesis of impaired receptor trafficking is most likely for mutations in the transmembrane domains of the receptor, particularly for those changes that occur in amino acids that are highly conserved among species and among $\mathrm{G}$ protein-coupled receptors in general, such as p.L173R, p.W178S and 
Table 3. Functional effects of $P R O K R 2$ mutations as determined by in vitro studies

\begin{tabular}{|c|c|c|c|c|c|c|}
\hline \multirow[t]{2}{*}{ Mutation } & \multirow{2}{*}{$\begin{array}{l}\text { Calcium } \\
\text { mobilization }\end{array}$} & \multirow{2}{*}{$\begin{array}{l}\text { MAPK } \\
\text { activation }\end{array}$} & \multirow[t]{2}{*}{ Binding assay } & \multicolumn{2}{|c|}{ PROKR2 quantification by ELISA } & \multirow[t]{2}{*}{ Ref. } \\
\hline & & & & permeabilized cells & nonpermeabilized cells & \\
\hline \multicolumn{7}{|c|}{ Mutations that affect ligand binding } \\
\hline p.Q210R & $60 \% \downarrow$ & $\mathrm{N} / \mathrm{A}$ & $95 \% \downarrow$ & $10 \% \downarrow$ & $10 \% \downarrow$ & {$[37]$} \\
\hline p.Y113H & $80 \% \downarrow$ & $90 \% \downarrow$ & $\mathrm{N} / \mathrm{A}$ & $\mathrm{N} / \mathrm{A}$ & $\mathrm{N} / \mathrm{A}$ & {$[34]$} \\
\hline p.V115M & $80 \% \downarrow$ & $70 \% \downarrow$ & $\mathrm{N} / \mathrm{A}$ & $\mathrm{N} / \mathrm{A}$ & $\mathrm{N} / \mathrm{A}$ & {$[34]$} \\
\hline \multicolumn{7}{|c|}{ Mutations that affect plasma membrane expression } \\
\hline p.L173R & $40-60 \% \downarrow$ & $95 \% \downarrow$ & $80 \% \downarrow$ & $50 \% \downarrow$ & $80 \% \downarrow$ & {$[34,37]$} \\
\hline p.W178S & $80 \% \downarrow$ & no activity & no binding & $60 \% \downarrow$ & $90 \% \downarrow$ & {$[34,37]$} \\
\hline p.S188L & no activity & no activity & $\mathrm{N} / \mathrm{A}$ & $\mathrm{N} / \mathrm{A}$ & $\mathrm{N} / \mathrm{A}$ & [34] \\
\hline p.P290S & no activity & $\mathrm{N} / \mathrm{A}$ & no binding & $60 \% \downarrow$ & $90 \% \downarrow$ & {$[37]$} \\
\hline \multicolumn{7}{|c|}{ Mutations that affect $\mathrm{G}$ protein interaction } \\
\hline p.R85C & $40 \% \downarrow$ & $10 \% \downarrow$ & $60 \% \downarrow$ & $40 \% \downarrow$ & $40 \% \downarrow$ & {$[34,37]$} \\
\hline p.R85H & $40 \% \downarrow$ & $\mathrm{N} / \mathrm{A}$ & $70 \% \downarrow$ & $40 \% \downarrow$ & $40 \% \downarrow$ & {$[37]$} \\
\hline p.R164Q & $60 \% \downarrow$ & $90 \% \downarrow$ & $=$ & $20 \% \downarrow$ & $20 \% \downarrow$ & {$[34,37]$} \\
\hline p.R248Q & $40 \% \downarrow$ & $=$ & $\mathrm{N} / \mathrm{A}$ & $\mathrm{N} / \mathrm{A}$ & $\mathrm{N} / \mathrm{A}$ & {$[34]$} \\
\hline p.R268C & $20 \% \downarrow$ & $\mathrm{N} / \mathrm{A}$ & $40 \% \downarrow$ & $20 \% \downarrow$ & $20 \% \downarrow$ & {$[37]$} \\
\hline p.V331M & $40-60 \% \downarrow$ & $=$ & $50 \% \downarrow$ & $30 \% \downarrow$ & $30 \% \downarrow$ & {$[34,37]$} \\
\hline p.R357W & $60 \% \downarrow$ & $=$ & $\mathrm{N} / \mathrm{A}$ & $\mathrm{N} / \mathrm{A}$ & $\mathrm{N} / \mathrm{A}$ & {$[34]$} \\
\hline \multicolumn{7}{|c|}{ Mutations that do not affect PROKR2 function } \\
\hline p.M323I & $=$ & $\mathrm{N} / \mathrm{A}$ & $=$ & $30 \% \downarrow$ & $40 \% \downarrow$ & {$[37]$} \\
\hline
\end{tabular}

Calcium mobilization experiments: aequorin-based luminescence assay or Fluo-4. MAPK activation experiments: Egr-1 luciferase activity. N/A: Not available; =: activity similar to wild-type.

p.P290S. These mutations resulted in reduced receptor levels in the plasma membrane [37]. Indeed, W178 and P290 are the most highly conserved amino acids in transmembrane domains 4 and 6 , respectively. Notably, a dominant negative effect of any of these PROKR2 missense mutants on the wild-type receptor was not found in vitro [37].

\section{Reversible Hypogonadotropic Hypogonadism due to PROKR2 Mutations}

A homozygous PROKR2 mutation, p.V274D, was identified in a male Kallmann syndrome patient who had presented with absent puberty. After 3.5 years of treatment with hCG and testosterone, he presented with reversal of hypogonadism after discontinuing hormonal therapy. He maintained oligospermia and testosterone levels in the low normal range for 2 years without any treatment [32]. In vitro studies were not performed to assess the effect of this mutation on receptor function. If p.V274D is an inactivating mutation, then this report suggests that PROKR2 can also regulate reproduction be- yond the stage of embryonic GnRH neuronal migration, as has been suggested for FGFR-1.

The presence of oligospermia in a patient with a homozygous PROKR2 mutation raises the issue of the role of the prokineticins in spermatogenesis. The long and short forms of PROK2 are expressed in human spermatocytes and PROKR2 is expressed in endothelial cells of the testis interstitium [38]. It is possible that the homozygous PROKR2 p.V274D mutation contributes directly to the oligospermia in this patient. In support of this possibility, a patient with normosmic hypogonadoptropic hypogonadism and a heterozygous p.W178S PROKR2 mutation presented with $\mathrm{LH}$ and FSH levels suggestive of GnRH deficiency as well as primary gonadal resistance [34]. The precise roles of PROK2 and PROKR2 in reproduction need further study for a better understanding.

\section{Conclusions}

The inactivation of the PROK2 system leads to defective olfactory morphogenesis and hypogonadism in mice and humans. Several mutations in PROK2 and PROKR2 
have been found in heterozygous, homozygous and compound heterozygous states in Kallmann syndrome and normosmic isolated hypogonadotropic hypogonadism, suggesting a complex mode of inheritance. A monogenic recessive mode of transmission has been demonstrated clearly, but in very few cases. Remarkably, many of the heterozygous mutations of $P R O K R 2$ have also been identified in clinically unaffected individuals, raising the question of their actual contribution to the hypogonadotropic hypogonadism phenotype. Moreover, a dominant negative effect of the heterozygous mutations of PROKR2 was not demonstrated by in vitro studies, arguing against a monogenic dominant transmission. Potential digenic and oligogenic transmissions have often been suggested; however, further studies will be necessary to confirm the actual pathogenic role of heterozygous PROKR2 mutations.

\section{Acknowledgments}

This work was supported by Fundação de Amparo à Pesquisa do Estado de São Paulo (FAPESP), grants 05/04726-0 and 06/56753-3 (to A.P.A.); Conselho Nacional de Desenvolvimento Científico e Tecnológico (CNPq), grant 300209/2008-8 (to A.C.L.), and the Eunice Kennedy Shriver NICHD/NIH through cooperative agreement U54 HD28138 as part of the Specialized Cooperative Centers Program in Reproduction and Infertility Research (to U.B.K.).

\section{References}

1 Li M, Bullock CM, Knauer DJ, Ehlert FJ, Zhou QY: Identification of two prokineticin cDNAs: recombinant proteins potently contract gastrointestinal smooth muscle. Mol Pharmacol 2001;59:692-698.

2 Bullock CM, Li JD, Zhou QY: Structural determinants required for the bioactivities of prokineticins and identification of prokineticin receptor antagonists. Mol Pharmacol 2004;65:582-588.

- 3 LeCouter J, Kowalski J, Foster J, Hass P, Zhang Z, Dillard-Telm L, Frantz G, Rangell L, DeGuzman L, Keller GA, Peale F, Gurney A, Hillan KJ, Ferrara N: Identification of an angiogenic mitogen selective for endocrine gland endothelium. Nature 2001;412:877884.

4 Chen J, Kuei C, Sutton S, Wilson S, Yu J, Kamme F, Mazur C, Lovenberg T, Liu C: Identification and pharmacological characterization of prokineticin 2 beta as a selective ligand for prokineticin receptor 1 . Mol Pharmacol 2005;67:2070-2076.

5 Ngan ES, Tam PK: Prokineticin-signaling pathway. Int J Biochem Cell Biol 2008;40: 1679-1684

6 Maldonado-Perez D, Evans J, Denison F, Millar RP, Jabbour HN: Potential roles of the prokineticins in reproduction. Trends Endocrinol Metab 2007;18:66-72.

7 Cheng MY, Bittman EL, Hattar S, Zhou QY: Regulation of prokineticin 2 expression by light and the circadian clock. BMC Neurosci 2005;6:17.

8 Cheng MY, Bullock CM, Li C, Lee AG, Bermak JC, Belluzzi J, Weaver DR, Leslie FM, Zhou QY: Prokineticin 2 transmits the behavioural circadian rhythm of the suprachiasmatic nucleus. Nature 2002;417:405-410.
9 Lin DC, Bullock CM, Ehlert FJ, Chen JL, Tian H, Zhou QY: Identification and molecular characterization of two closely related $G$ protein-coupled receptors activated by prokineticins/endocrine gland vascular endothelial growth factor. J Biol Chem 2002;277: 19276-19280.

10 Masuda Y, Takatsu Y, Terao Y, Kumano S, Ishibashi Y, Suenaga M, Abe M, Fukusumi S, Watanabe T, Shintani Y, Yamada T, Hinuma $\mathrm{S}$, Inatomi N, Ohtaki T, Onda H, Fujino M: Isolation and identification of EG-VEGF/ prokineticins as cognate ligands for two orphan G-protein-coupled receptors. Biochem Biophys Res Commun 2002;293:396-402.

11 Soga T, Matsumoto S, Oda T, Saito T, Hiyama H, Takasaki J, Kamohara M, Ohishi T, Matsushime H, Furuichi K: Molecular cloning and characterization of prokineticin receptors. Biochim Biophys Acta 2002;1579:173-179.

12 Lin R, LeCouter J, Kowalski J, Ferrara N: Characterization of endocrine gland-derived vascular endothelial growth factor signaling in adrenal cortex capillary endothelial cells. J Biol Chem 2002;277:8724-8729.

13 Zhang C, Truong KK, Zhou QY: Efferent projections of prokineticin 2 expressing neurons in the mouse suprachiasmatic nucleus. PLoS One 2009;4:e7151.

-14 Ng KL, Li JD, Cheng MY, Leslie FM, Lee AG, Zhou QY: Dependence of olfactory bulb neurogenesis on prokineticin 2 signaling. Science 2005;308:1923-1927.

15 Matsumoto S, Yamazaki C, Masumoto KH, Nagano M, Naito M, Soga T, Hiyama H, Matsumoto M, Takasaki J, Kamohara M, Matsuo A, Ishii H, Kobori M, Katoh M, Matsushime H, Furuichi K, Shigeyoshi Y: Abnormal development of the olfactory bulb and reproductive system in mice lacking prokineticin receptor PKR2. Proc Natl Acad Sci USA 2006;103:4140-4145.
16 Pitteloud N, Zhang C, Pignatelli D, Li JD, Raivio T, Cole LW, Plummer L, JacobsonDickman EE, Mellon PL, Zhou QY, Crowley WF Jr: Loss-of-function mutation in the prokineticin 2 gene causes Kallmann syndrome and normosmic idiopathic hypogonadotropic hypogonadism. Proc Natl Acad Sci USA 2007;104:17447-17452.

17 Cheng MY, Leslie FM, Zhou QY: Expression of prokineticins and their receptors in the adult mouse brain. J Comp Neurol 2006;498: 796-809.

18 Prosser HM, Bradley A, Chesham JE, Ebling FJ, Hastings MH, Maywood ES: Prokineticin receptor 2 (Prokr2) is essential for the regulation of circadian behavior by the suprachiasmatic nuclei. Proc Natl Acad Sci USA 2007; 104:648-653.

19 Hu WP, Li JD, Zhang C, Boehmer L, Siegel JM, Zhou QY: Altered circadian and homeostatic sleep regulation in prokineticin 2-deficient mice. Sleep 2007;30:247-256.

20 Li JD, Hu WP, Boehmer L, Cheng MY, Lee AG, Jilek A, Siegel JM, Zhou QY: Attenuated circadian rhythms in mice lacking the prokineticin 2 gene. J Neurosci 2006;26:1161511623.

21 Schwanzel-Fukuda M: Origin and migration of luteinizing hormone-releasing hormone neurons in mammals. Microsc Res Tech 1999;44:2-10.

22 Tsai PS, Gill JC: Mechanisms of disease: insights into X-linked and autosomal-dominant Kallmann syndrome. Nat Clin Pract Endocrinol Metab 2006;2:160-171.

23 Albuisson J, Pecheux C, Carel JC, Lacombe D, Leheup B, Lapuzina P, Bouchard P, Legius E, Matthijs G, Wasniewska M, Delpech M, Young J, Hardelin JP, Dode C: Kallmann syndrome: 14 novel mutations in KAL1 and FGFR1 (KAL2). Hum Mutat 2005;25:98-99. 
24 Hardelin JP, Levilliers J, Blanchard S, Carel JC, Leutenegger M, Pinard-Bertelletto JP, Bouloux P, Petit C: Heterogeneity in the mutations responsible for $\mathrm{X}$ chromosomelinked Kallmann syndrome. Hum Mol Genet 1993;2:373-377.

-25 Salenave S, Chanson P, Bry H, Pugeat M, Cabrol S, Carel JC, Murat A, Lecomte P, Brailly S, Hardelin JP, Dode C, Young J: Kallmann's syndrome: a comparison of the reproductive phenotypes in men carrying KAL1 and FGFR1/KAL2 mutations. J Clin Endocrinol Metab 2008;93:758-763.

26 Dode C, Levilliers J, Dupont JM, De Paepe A, Le Du N, Soussi-Yanicostas N, Coimbra RS, Delmaghani S, Compain-Nouaille S, Baverel F, Pecheux C, Le Tessier D, Cruaud C, Delpech M, Speleman F, Vermeulen S, Amalfitano A, Bachelot Y, Bouchard P, Cabrol S, Carel JC, Delemarre-van de Waal H, GouletSalmon B, Kottler ML, Richard O, SanchezFranco F, Saura R, Young J, Petit C, Hardelin JP: Loss-of-function mutations in FGFR1 cause autosomal dominant Kallmann syndrome. Nat Genet 2003;33:463-465.

-27 Falardeau J, Chung WC, Beenken A, Raivio T, Plummer L, Sidis Y, Jacobson-Dickman EE, Eliseenkova AV, Ma J, Dwyer A, Quinton R, Na S, Hall JE, Huot C, Alois N, Pearce SH, Cole LW, Hughes V, Mohammadi M, Tsai P, Pitteloud N: Decreased FGF8 signaling causes deficiency of gonadotropin-releasing hormone in humans and mice. J Clin Invest 2008;118:2822-2831.

-28 Kim HG, Kurth I, Lan F, Meliciani I, Wenzel W, Eom SH, Kang GB, Rosenberger G, Tekin M, Ozata M, Bick DP, Sherins RJ, Walker SL, Shi Y, Gusella JF, Layman LC: Mutations in CHD7, encoding a chromatin-remodeling protein, cause idiopathic hypogonadotropic hypogonadism and Kallmann syndrome. Am J Hum Genet 2008;83:511-519.
29 Dodé C, Teixeira L, Levilliers J, Fouveaut C, Bouchard P, Kottler ML, Lespinasse J, Lienhardt-Roussie A, Mathieu M, Moerman A, Morgan G, Murat A, Toublanc JE, Wolczynski S, Delpech M, Petit C, Young J, Hardelin JP: Kallmann syndrome: mutations in the genes encoding prokineticin- 2 and prokineticin receptor-2. PLoS Genet 2006;2:e175.

30 Abreu AP, Trarbach EB, de Castro M, Frade Costa EM, Versiani B, Matias Baptista MT, Garmes HM, Mendonca BB, Latronico AC: Loss-of-function mutations in the genes encoding prokineticin- 2 or prokineticin receptor- 2 cause autosomal recessive Kallmann syndrome. J Clin Endocrinol Metab 2008;93: 4113-4118.

31 Leroy C, Fouveaut C, Leclercq S, Jacquemont S, Boullay HD, Lespinasse J, Delpech M, Dupont JM, Hardelin JP, Dode C: Biallelic mutations in the prokineticin-2 gene in two sporadic cases of Kallmann syndrome. Eur J Hum Genet 2008;16:865-868.

32 Sinisi AA, Asci R, Bellastella G, Maione L, Esposito D, Elefante A, De Bellis A, Bellastella A, Iolascon A: Homozygous mutation in the prokineticin-receptor2 gene (Va1274Asp) presenting as reversible Kallmann syndrome and persistent oligozoospermia: case report. Hum Reprod 2008;23:23802384.

33 Canto P, Munguia P, Soderlund D, Castro JJ, Mendez JP: Genetic analysis in patients with Kallmann syndrome: coexistence of mutations in prokineticin receptor 2 and KAL1. J Androl 2009;30:41-45.
34 Cole LW, Sidis Y, Zhang C, Quinton R, Plummer L, Pignatelli D, Hughes VA, Dwyer AA, Raivio T, Hayes FJ, Seminara SB, Huot C, Alos N, Speiser P, Takeshita A, Van Vliet G, Pearce S, Crowley WF Jr, Zhou QY, Pitteloud $\mathrm{N}$ : Mutations in prokineticin 2 and prokineticin receptor 2 genes in human gonadotrophin-releasing hormone deficiency: molecular genetics and clinical spectrum. J Clin Endocrinol Metab 2008;93:3551-3559.

35 Chan YM, de Guillebon A, Lang-Muritano M, Plummer L, Cerrato F, Tsiaras S, Gaspert A, Lavoie HB, Wu CH, Crowley WF Jr, Amory JK, Pitteloud N, Seminara SB: GNRH1 mutations in patients with idiopathic hypogonadotropic hypogonadism. Proc Natl Acad Sci USA 2009;106:11703-11708.

36 Sarfati J, Guiochon-Mantel A, Rondard P, Arnulf I, Garcia-Pinero A, Wolczynski S, Brailly-Tabard S, Bidet M, Arroyo R, Mathieu M, Lienhardt-Roussie A, Morgan G, Turki Z, Bremont C, Lespinasse J, Du Boullay $\mathrm{H}$, Chabbert-Buffet $\mathrm{N}$, Jacquemont $\mathrm{S}$, Reach G, De Talence N, Tonella P, Conrad B, Despert F, Delobel B, Brue T, Bouvattier C, Cabrol S, Pugeat M, Murat A, Bouchard P, Hardelin JP, Dode C, Young J: A comparative phenotypic study of kallmann syndrome patients carrying monoallelic and biallelic mutations in the prokineticin 2 or prokineticin receptor 2 genes. J Clin Endocrinol Metab 2010;95:659-669.

37 Monnier C, Dode C, Fabre L, Teixeira L, Labesse G, Pin JP, Hardelin JP, Rondard P: PROKR2 missense mutations associated with Kallmann syndrome impair receptor signalling activity. Hum Mol Genet 2009;18: 75-81.

-38 Wechselberger C, Puglisi R, Engel E, Lepperdinger G, Boitani C, Kreil G: The mammalian homologues of frog Bv8 are mainly expressed in spermatocytes. FEBS Lett 1999; 462:177-181. 